\title{
Inventory of Geoheritage Sites - the Base of Geotourism Development in Montenegro
}

\author{
Đurović Predrag ${ }^{\mathrm{A}}$, Đurović Mirela ${ }^{\mathrm{B}}$ \\ Received: November 2010 | Revised: November 2010 | Accepted: November 2010
}

\begin{abstract}
The main principles and methodology of establishing the inventory of geoheritage sites are analyzed. Special attention is given to theoretical and practical problems related to application of the established principles. Geoheritage sites in Montenegro, classified according to international standards [ProGeo] were presented, including their valorization based on the aspects of tourism valorization. Possibilities and limitations of geotourism development in Montenegro were emphasized, too.
\end{abstract}

Key words: geodiversity, geoheritage, tourism, geotourism, Montenegro

\section{Principles and methodology of establishing the inventory of geoheritage sites}

Geotectonic base and exogenous processes brought to distinctive complex of natural, abiotic elements within the particular area. These elements construct the overall diversity known as geodiversity. Geodiversity objects should be recognized and study during the special scientific studies among different geodisciplines. Extensive studies enlarge our knowledge related to geodiversity of distinct area. However, more apparent insight into the geodiversity wealth requires the distinguishing of representative objects, i.e. geoheritage sites as representatives of geodiversity (Djurović P., Mijović $\mathrm{D}$, 2006). These include geological, geomorphological, hydrological-hydrogeological, pedological and distinct, geo-archeological values emphasized with their notable scientific and cultural significance, making a part of distinct European and world heritage. From that reason they require to be concerned of all relevant social factors in their protection as well as in their presentation to domestic and foreign scientific and professional publicity (Pantić N., Belij S., Mijović D., I998).

Geoheritage sites differ a lot concerning their forms and essential values. These differences could cause some problems during their inventory, protection as well as during their presentation. Concerning their forms should be distinguished dotted, aerial and linear forms, whereas concerning size exist sites in meter scale, decameter and kilometer scale. Dotted geoheritage sites of meter and decameter size might be incorporated into linear or aerial objects of kilometer size. This actually means that geoheritage sites could be simple or complex. For example, the canyon of the Tara River was determined as linear geoheritage object in kilometer scale. It represents complex site, as embraces several pointless sites in decameter scale e.g. springs Ljutica, Bijelo vrelo, Bajlovića sige, Djavolje lazi etc. (Djurović P., Djurović M., 20Io).

Distinguishing of geoheritage sites among the geodiversity objects is possible concerning few criteria: scientific values, rarity, original, representative, aesthetic etc. The group of representative objects - geoheritage sites determined within the geodiversity objects, need to be categorized, i.e. its importance related to similar objects need to be evaluated. Categorization is usually among the sites of local, national, regional, European and world importance (Dangić A., I998). Their identification and classification should be followed with their protection and conservation. Different protection measures based on different law acts de-

\footnotetext{
A Geography faculty, University of Belgrade; Studentski trg 3/III, 11000 Belgrade, Serbia; e-mail: geodjura@eunet.rs

B Jurija Gagarina 117/111, 11000 Belgrade, Serbia; e-mail: e-mai: mirela.djurovic5@gmail.com

* Corresponding author: Đurović Predrag, e-mail: geodjura@eunet.rs
} 
pending from the worthy of the sites, their temporary and potential endanger, will be applied. At some geoheritage sites, applied conservation should prevent further deterioration. Conservation includes physical protection of sites from the influence of natural processes and anthropogenic impacts. Simultaneously with conservation and protection should be done valorization and presentation of geoheritage sites. Presentation of geoheritage sites should be directly at their site or indirectly. Former includes either the exposition of panels, which will present the main site values, or organization of leader services. The latter includes presentation in various publications, scientific (magazines, monographs etc.), professional (books, reference books etc.) and popular (itinerary, guide books etc.) as well as in medias like television or newspaper reports and so on. Valorization of geoheritage sites is based on different criteria depending from the object themselves. Valorization is often in discordance with the protection, as could decrease its importance, or destroy it.

\section{Touristic valorization of geoheritage sites}

From the above-mentioned modes of inventory of geoheritage sites creation is obvious that it represents a long and complex process, both scientific and professional, as well as legislative.With this process, or near its end, could be created valorization of geoheritage sites in the sense of its value for tourism. Principles of tourist valorization are different from principles of distinguishing geodiversity objects and valorization of geoheritage sites. These differences are the consequence of different criteria for the geoheritage sites valorization. A scientific criterion, which is the main decisive factor in selection of geoheritage sites, is not the main in tourist valorization, where the advantage belongs to aesthetic values and rarity. Communication and economic defray are two approaches which highly govern tourism valorization of geoheritage sites. The highest attraction deserves complex sites of aerial or linear distribution, kilometer in scale (Figure and 2).

\section{Geoheritage sites in Montenegro}

Geotectonic setting and physical-geographical conditions resulted in formation of numerous and diverse, natural geo-complexes in Montenegro. Accompanied with biotic elements they represent a true complex of natural diversity in this area (Radojičić B., I996).

Several macro geotectonic units have been divided in Montenegro: Dinarides, Prokletije and coast-

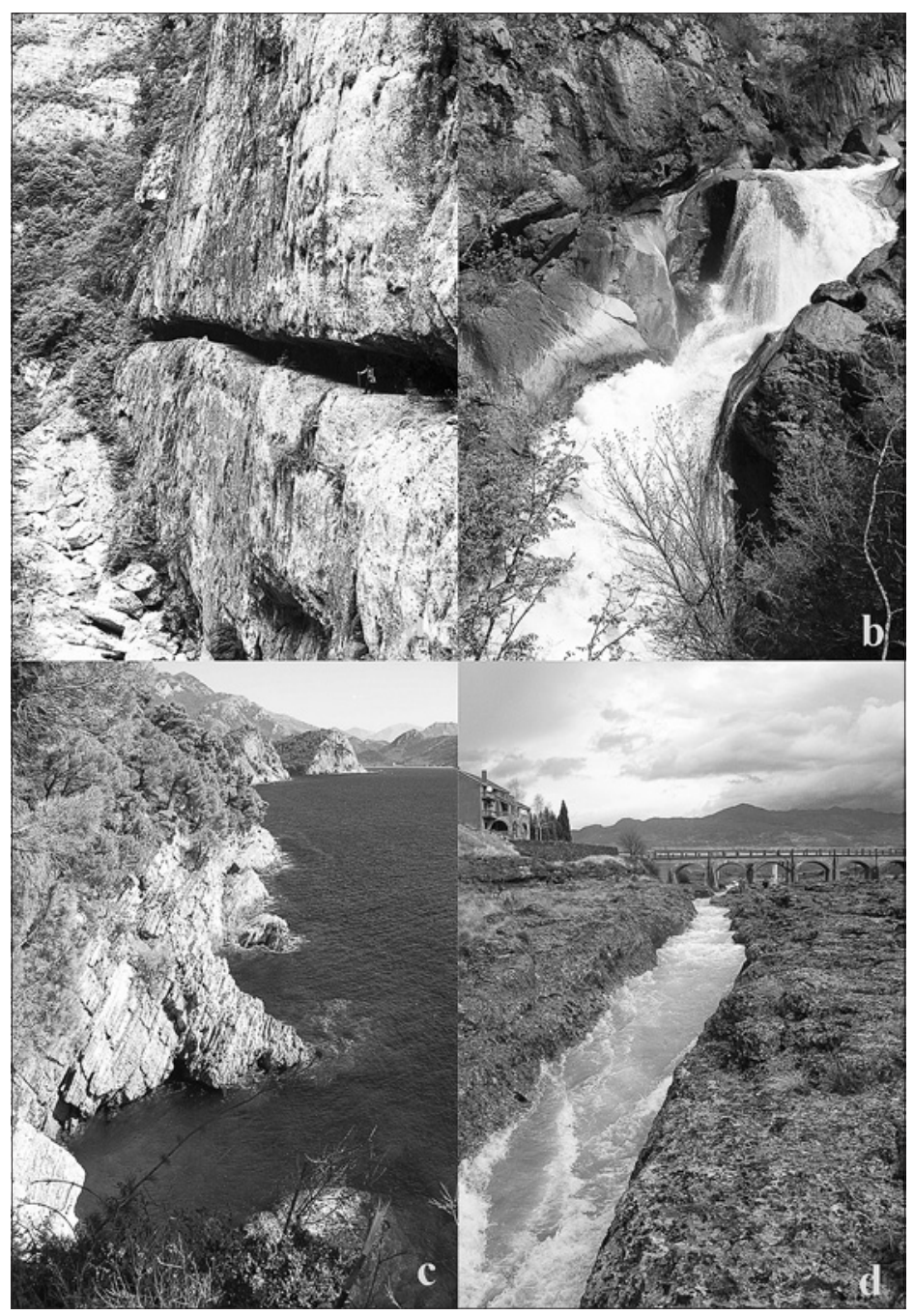

Figure 1. Geoheritage of Montenegro:

a] Canyon of the Mrtvica River [Southwest from Kolašin], b] Waterfall of the Perućica River, c] Cliff near Petrovac [on the Adriatic Coast] , d] Riverbed of Cijevna [near Podgorica]

al Adriatic region (Ivanović S., I99I). Each of these geotectonic units past through different evolution phases, thus their petrological and structural elements witness of thundering evolution in this part of the Europe. Different physical-geographical factors, both in modern times and in ancient geomorphological past, imprinted the existing geological basement creating a treasure of different forms, occurrences and processes (Figure I and 2). The highest influence on nature in Montenegro had two noteworthy changes. They correspond to alternation of glacial and interglacial periods that took part approximately in last 2 million years. These alternations either caused motions, or stopped the numerous physical-geographical processes. They had the direct influence on highland-mountainous region whereas the complete Montenegro area affected indirectly. Another significant change is related for the rise of Adriatic Sea level as the consequence of global sea level increase. This happened about I2 -I4,000 years ago and resulted in drown- 

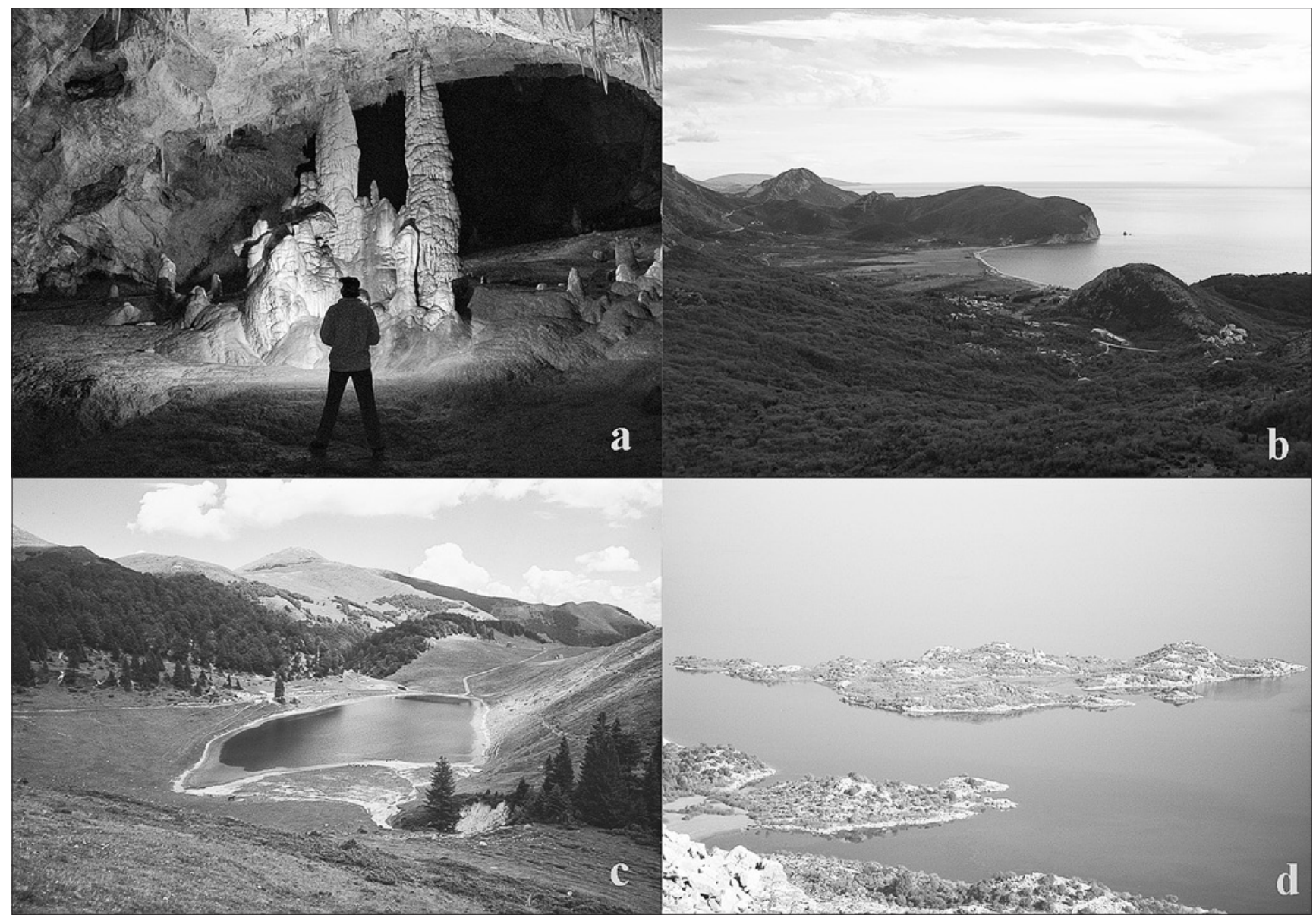

Figure 2. Geoheritage of Montenegro: a] Lipska Pećina [cave near Cetinje], b] Buljarica [bay near Petrovac on the Adriatic Coast], c] Pešića jezero [lake on the Mount Bjelasica], d] Beška [island in the Skadar Lake]

ing of previous relief and translation of landforms into submerge forms (submarine springs, drowned springs, drowned karst valleys called vrtače, karst fields etc.).

\section{Inventory of geoheritage sites}

Geoheritage sites are classified into 9 main groups:

- historical-geological and stratigraphically sites heritage,

- structural sites,

- petrological sites,

- geomorphological sites,

- neo-tectonic activities sites,

- speleological sites,

- hydrological-hydrogeological sites,

- pedological sites and

- archeological geoheritage sites (Wimbledon W.A.P. 1996,1999).

\section{State and perspectives of tourist valorization of geoheritage sites in Montenegro}

The official inventory of geoheritage sites in Montenegro does not exist. A group of authors made some preliminary list. It embraces small number of sites related to their real number in Montenegro (Djurović P., Djurović M., 20IO). According to this preliminary list the existence of diverse geoheritage sites in Montenegro, whose values often exceed local importance, is designated. Numerous sites occur as significant natural curiosities beside their pronounced scientific values representing very good potentials for tourism development. The most valuable are sites of geomorphological, hydrological, and partly sites of speleological geoheritage (Lješević M. I980). Deep karst is prevailing in Montenegro, thus pits are the most abundant. Although caves are not so numerous, some of them have notable aesthetic values. Historical-geological geoheritage sites represent lesser objects of tourist valorization. However, some of them accompanied with the proper informative puncts might evaluate into touristic destinations especially those able to offer and present the evolution of the Earth on suitable way for visitors. The example is the spring Smrdan in Crmnica that spurts sporadically methane bubbles etc.

Geoheritage sites in Montenegro are partly included as natural rarities into touristic offer. In the frame of touristic presentation, the Ministry of tourism placed along the important roads 
cursors that point onto distinct objects of natural or cultural-historical significance. Geoheritage sites are included in these signed objects. However, touristic valorization was not carried out planned and systematically, just for the particular sites. Well-defined criterion for selection of pointed sites was lacking too. Some sites without wellarranged paths, although dangerous for potential visitors, were also assigned (the well Ljutica in the Tara river canyon). This concerns especially speleological objects, which were not arrange yet, as well as objects accessible through rough and risky paths. Mentioned cursors embraced a negligible number of sites, whereas the majority of them remained without any adequate sign or instruction for potential visitors.

Hydrological geoheritage sites should be noted and underlined as examples of positive and good touristic valorization, e.g. karst spring Ravnjak (between Mojkovac and Žabljak), springs of Alipaša (Gusinje), Glava Zete (near Danilovgrad) etc. These places mark significant number of visitors, but the proper information about the value of these sites worthy to visit is still missing. Springs in Boka Kotorska are without touristic offer although they display extraordinary and rare properties, thus remain unknown to numerous tourists that only pass by. The spring Ljuta, for example, has maximal discharge over $180 \mathrm{~m} 3 / \mathrm{s}$ with a channel depth over Ioo $\mathrm{m}$. Cave channels, which brought water for the spring Gurdić and Sopot, penetrate deep beneath the sea surface.

Aerial distribution of the geoheritage sites is extremely good. They are uniformly distributed in the coastal area as well as in medium, central and mountainous region. Numerous sites are close to main roads and big cities, as well as close to tourist destinations, enabling their easier valorization. Touristic arrangement in the adjacent vicinity of some sites remained unsolved, as completely absent or inadequately and insufficiently obtained. It should be noted that the people dealing with tourism are not either well or enough informed about geoheritage sites and their touristic values. That is the main reason for the absence of any idea concerning their presentation and their assessment into touristic offer living numerous interesting sites out of tourist offering.

The existing touristic maps of Montenegro contain small number of data related to geoheritage sites, commonly only its location without any additional notes concerning its value. Tourist guidebooks are better supply with information but still are far from correct presentation of all geoheritage sites and their values. Geoheritage sites are best explained and presented in scientific monographs with touristic content, but as natural rarities of particular places instead as geo- heritage sites (Nikolić S., 2000). Another problem arose from their application within scientific population, not among tourists.

Creation of tourist map with positions of the most important geoheritage sites would pay attention of tourists and force their visiting. This map should contain beside the exact position of the site, its value and importance, what will allow tourists to choose objects of interests concerning their own affinities.

The arrangement of the adjacent vicinity of geoheritage sites should be (cursors, approaches, paths, protective fences etc.), under municipal tourist organizations and responsible Ministry, as well as the methods of their proper touristic valorization (tickets etc.).

\section{Conclusion}

Small number of geoheritage sites in Montenegro was touristic valorized up to now. Taking into consideration that the present touristic offer, mostly related for coastal tourism has reached its real maximum, and that the mountainous tourism is highly dependable from the surrounding competition, the main goal in the future is geotourism development, i.e. valorization of the most important geoheritage sites. These require establishing a conscience about the geoheritage, its value and importance, starting from the municipal tourist organizations and direct realisators of touristic offerings (touristic agencies, tourismologists, touristic guides etc.). Pronounce education of touristic workers is necessary for realization of suggested task. On the other side, skills for arrangement of selected geoheritage objects must be directed. All of these demand significant activities related for touristic marketing mostly concerned to creation of General Geotouristic map of Montenegro, as well as geotouristic maps for particular areas of touristic interest in Montenegro, respectively.

\section{References}

Dangić, A. 1995/97. Geological heritage of Serbia identification, categorization and protection of heritage objects. Zaštita prirode 48-49, 7I-78. (in Serbian)

Djurović, P., Mijović, D. 2006. Geoheritage of Serbia: Representative of its total geodiversity. Zbornik radova LIV, 4-I8. (in Serbian)

Djurović, P., Djurović, M. 20Io. Geoheritage sites reprezentatives of Geodiversity of Montenegro. Simpozijum: Geoekologija - XXI vijek, Žabljak, Nikšić, 508-517. (in Serbian)

Ivanović, S. I99I. Earthquake phenomena of nature. CANU, Gradjevninski fakultet Podgorica, Podgorica. (in Serbian) 
Lješević, M., Barović, V. I98I. The Greatest Speleological Objects of Montenegro. Osmi jugoslovenski speleološki kongres, Beograd, 20I-205. (in Serbian)

Nikolić, S. 2000. Nature and Tourism in Montenegro. Republički zavod za zaštitu prirode Crne Gore, Podgorica. (in Serbian)

Pantić, N., Belij, S., Mijović, D. I998. Geological heritage in the system of natural values and its protection in Serbia. Zaštita prirode 50, 407-4I3. (in Serbian)
Radojičić, B. I996. Geography of Montenegro: Natural Ground Plan. Nikšić. (in Serbian)

Wimbledon, W.A.P. 1996. National site selection, a stop on the road to Europen Geosites list. Geologica Balkanica, Special issue Geological Heritage, BAN, I5-28.

Wimbledon, W.A.P. 1999. Geosites - an International Union of Geological Sciences initiative to conserve our geological heritage. Polish Geological Institute, Special Papers 2, 5-8.

Appendix - Inventory list of geoheritage sites in Montenegro

\begin{tabular}{|c|c|c|}
\hline № & Name & Location \\
\hline 1 & $\begin{array}{l}\text { Devonian sediments in the } \\
\text { upper river Grnčarevska }\end{array}$ & $\begin{array}{l}\text { Northwest of Bijelo Polje } \\
\text { [paleontological records]. }\end{array}$ \\
\hline 2 & $\begin{array}{l}\text { Devonian-carbon sediments } \\
\text { in the upper course of the } \\
\text { Ibar }\end{array}$ & $\begin{array}{l}\text { Upstream of Rožaje } \\
\text { [paleontological records] } \\
\text { [findings Conodonts } \\
\text { genera and species, } \\
\text { foraminifera, flora, } \\
\text { stromatoporida et al. }\end{array}$ \\
\hline 3 & $\begin{array}{l}\text { Carboniferous sediments } \\
\text { Turjak }\end{array}$ & Rožaje \\
\hline 4 & $\begin{array}{l}\text { Permian sediments in the } \\
\text { valley Ćehotina }\end{array}$ & $\begin{array}{l}\text { Near the village } \\
\text { Skenderovine, } \\
\text { downstream from Pljevlja } \\
\text { [paleontological records] }\end{array}$ \\
\hline 5 & $\begin{array}{l}\text { Lower Jurassic sediments } \\
\text { [Lias inner areas] }\end{array}$ & Environment Vilusi \\
\hline 6 & $\begin{array}{l}\text { Lower Jurassic sediments, } \\
\text { [complete Lias] }\end{array}$ & Canyon Mrtvica \\
\hline 7 & Middle Triassic sediments & Gornje polje Nikšić \\
\hline 8 & $\begin{array}{l}\text { Lower Cretaceous } \\
\text { sediments }\end{array}$ & The Budoš near Petrović \\
\hline 9 & $\begin{array}{l}\text { Upper Cretaceous } \\
\text { sediments }\end{array}$ & $\begin{array}{l}\text { Jelina pećina south of } \\
\text { Nikšić }\end{array}$ \\
\hline 10 & Neogene sediments & Brezna \\
\hline 11 & Middle Miocene sediments & $\begin{array}{l}\text { Mendara, NW of Ulcinj, } \\
\text { [paleontological records } \\
\text { benthic foraminifera } \\
\text { form] }\end{array}$ \\
\hline 12 & $\begin{array}{l}\text { Orijensko-bjelogorski } \\
\text { synclinorium }\end{array}$ & Mt. Orijen \\
\hline 13 & $\begin{array}{l}\text { Old Montenegrin } \\
\text { anticlinorium }\end{array}$ & Podgorica - Nikšić \\
\hline 14 & Anticline Velji Garač & Danilovgrad \\
\hline 15 & Anticline Platija & Podgorica - Kolašin \\
\hline 16 & Anticline Sadjevice & South of Danilovgrad \\
\hline 17 & $\begin{array}{l}\text { Anticline Možure i Brivske } \\
\text { gore }\end{array}$ & Ulcinj \\
\hline 18 & Lješanska fault & Near Podgorica \\
\hline 19 & Raslovački fault & Between Lutovo and Bioče \\
\hline 20 & Fault Brezovih Rupa & Bioče \\
\hline 21 & Sušički fault & West of Danilovgrad \\
\hline 22 & Kraljušt Martinića & Danilovgrad \\
\hline
\end{tabular}

\begin{tabular}{|c|c|c|}
\hline № & Name & Location \\
\hline 23 & Kraljušt Meduna & Podgorica \\
\hline 24 & $\begin{array}{l}\text { Quartz diorite of the } \\
\text { Paleozoic }\end{array}$ & $\begin{array}{l}\text { Intrusives in the form } \\
\text { of bodies or wires in the } \\
\text { valley of NW Lješnica } \\
\text { Bijelo Polje }\end{array}$ \\
\hline 25 & Kornit Paleozoic & NW of Bijelo Polje \\
\hline 26 & $\begin{array}{l}\text { Paleozoic quartz } \\
\text { keratophyre }\end{array}$ & $\begin{array}{l}\text { [Revised and } \\
\text { metamorphed volcanics] } \\
\text { in the valley Ljuboviđa NW } \\
\text { of Bijelo Polje }\end{array}$ \\
\hline 27 & $\begin{array}{l}\text { Middle Triassic igneous } \\
\text { rocks [tuffs, tifiti, volcanic } \\
\text { breccia] }\end{array}$ & $\begin{array}{l}\text { Bijela Crkva northeast of } \\
\text { Rožaje }\end{array}$ \\
\hline 28 & Middle Triassic rhyolite & $\begin{array}{l}\text { Kozička River valley, } \\
\text { between the villages } \\
\text { Kozice and Vrulja [NW of } \\
\text { Kovren] }\end{array}$ \\
\hline 29 & Triassic tuffs & Near Kovren \\
\hline 30 & Spiliti jure & $\begin{array}{l}\text { In the valley of the Bistrica } \\
\text { River, near the village of } \\
\text { Bistrica }\end{array}$ \\
\hline 31 & Middle Triassic andesite & $\begin{array}{l}\text { On the Mt. Ljubišnja, } \\
\text { Šuplja stijena }\end{array}$ \\
\hline 32 & Middle Triassic dacite & $\begin{array}{l}\text { On the Mt. Ljubišnja, the } \\
\text { source of rivers River }\end{array}$ \\
\hline 33 & $\begin{array}{l}\text { Secondary metric } \\
\text { hydrothermally altered } \\
\text { andesite and dacite [lead } \\
\text { and zinc] }\end{array}$ & Šiplja stijena \\
\hline 34 & $\begin{array}{l}\text { Volcano-sedimentary series } \\
\text { of ladinic [bentonites] }\end{array}$ & $\begin{array}{l}\text { SW of Virpazar [Bijelo } \\
\text { Polje] }\end{array}$ \\
\hline 35 & $\begin{array}{l}\text { Verfen dolomite and shale } \\
\text { [barite, hydrothermal origin] }\end{array}$ & $\begin{array}{l}\text { Between Sutomore and } \\
\text { Mišići [Spič] }\end{array}$ \\
\hline 36 & $\begin{array}{l}\text { Dolomite and clastic } \\
\text { sediments mercury }\end{array}$ & Sozina \\
\hline 37 & $\begin{array}{l}\text { Sedimentary origin limonite } \\
\text { [iron] }\end{array}$ & $\begin{array}{l}\text { Between Petrovac and } \\
\text { Virpazar }\end{array}$ \\
\hline 38 & $\begin{array}{l}\text { Hydrothermally altered } \\
\text { andesite and dacite } \\
\text { Anisian [iron in the form of } \\
\text { hematite] }\end{array}$ & Krnja Jela \\
\hline 39 & $\begin{array}{l}\text { Cenomanian limestones } \\
\text { [bituminous shale] }\end{array}$ & Locale Hum and Božaj \\
\hline
\end{tabular}




\begin{tabular}{|c|c|c|}
\hline № & Name & Location \\
\hline 40 & $\begin{array}{l}\text { Upper Cretaceous limestone } \\
\text { [asphalt] }\end{array}$ & West of Ulcinj \\
\hline 41 & Miocene sediments [asphalt] & South of Ulcinj \\
\hline 42 & $\begin{array}{l}\text { Verfens slate [occasional } \\
\text { outbreaks of blisters natural } \\
\text { gas and oil droplets] }\end{array}$ & Smrdan, Crmnica \\
\hline 43 & $\begin{array}{l}\text { Series of Middle } \\
\text { Triassic limestones and } \\
\text { conglomerates [oil and gas] }\end{array}$ & Buljarica \\
\hline 44 & $\begin{array}{l}\text { Volcano-sedimentary series } \\
\text { [manganese] }\end{array}$ & Near Mažići Budva \\
\hline 45 & $\begin{array}{l}\text { Red bauxite Middle and } \\
\text { Upper Triassic [Triassic } \\
\text { horizon] }\end{array}$ & $\begin{array}{l}\text { Oldest bauxite } \\
\text { Montenegro, Niksicka } \\
\text { župa }\end{array}$ \\
\hline 46 & $\begin{array}{l}\text { Red bauxite between } \\
\text { Liassic and Upper Tithonian } \\
\text { [Jurassic horizon] }\end{array}$ & Nikšićka župa \\
\hline 47 & Graffiti, hydrothermal origin & Mt. Prekornica \\
\hline 48 & Travertine & Tomaševo, Bijelo Polje \\
\hline 49 & Travertine & Pljevlja \\
\hline 50 & Travertine & Pjevalja \\
\hline 51 & Travertine, Podmalinsko & Boan \\
\hline 52 & Lakes sediments & Plavnca, Skadar Lake \\
\hline 53 & Lakes sediments & Šasko jezero Lake \\
\hline 54 & $\begin{array}{l}\text { Lakes, Pleistocene } \\
\text { sediments }\end{array}$ & Nikšićko polje \\
\hline 55 & Rumija-Lovćen block uplift & Mt. Rumija \& Mt. Lovćen \\
\hline 56 & Orijen block uplift & Mt. Orijen \\
\hline 57 & Njeguši block uplift & Mt. Lovćen \\
\hline 58 & Maganik block uplift & Mt. Maganik \\
\hline 59 & $\begin{array}{l}\text { Skadar- Zeta blok lowering } \\
\text { block }\end{array}$ & Skadar Lake \\
\hline 60 & $\begin{array}{l}\text { Petrovac - Budva lowering } \\
\text { block }\end{array}$ & Budva \\
\hline 61 & Talus cones & Mt. Komovi \\
\hline 62 & Karst windows & Canyon Piva \\
\hline 63 & Karst windows & Karanfili - Mt.Prokletije \\
\hline 64 & Canyon Cijevna & Near Podgorica \\
\hline 65 & Canyon Kazani & Ćehotina \\
\hline 66 & Canyon Piva & \\
\hline 67 & Canyon Sušica & \\
\hline 68 & Canyon Komarnica & \\
\hline 69 & Canyon Tara & \\
\hline 70 & Canyon Draga & \\
\hline 71 & Canyon Lim & \\
\hline 72 & Canyon Đalovića klisura & \\
\hline 73 & Canyon Pridvarica & \\
\hline 74 & Canyon Bukovica & \\
\hline 75 & Canyon Mrtvica & \\
\hline 76 & Canyon Morača & \\
\hline 77 & Canyon Trebješnica & \\
\hline 78 & Canyon Kruševica stream & \\
\hline 79 & Canyon Mala Rijeka & \\
\hline
\end{tabular}

\begin{tabular}{|c|c|c|}
\hline № & Name & Location \\
\hline 80 & Canyon Žljeb & \\
\hline 81 & Canyon Radman river & \\
\hline 82 & Canyon Ibar & \\
\hline 83 & Canyon Škurda & \\
\hline 84 & Canyon Cijevna - upper & \\
\hline 85 & Canyon Brcka & \\
\hline 86 & Canyon Rikavac & \\
\hline 87 & Canyon Vruća rijeka & \\
\hline 88 & Canyon Starobarska rijeka & \\
\hline 89 & Canyon Grlja & \\
\hline 90 & Riverbed Cijevne [bottom] & Podgorica \\
\hline 91 & Epigenic Ćehotina river & Pljevalja \\
\hline 92 & Epigenic Skakavac river & Vusanje-Gusinje \\
\hline 93 & $\begin{array}{l}\text { Piracy river Ljubovidja and } \\
\text { Ćehotina }\end{array}$ & Kovren \\
\hline 94 & $\begin{array}{l}\text { Piracy Medjurečka rijeka } \\
\text { river }\end{array}$ & Ulcinj \\
\hline 95 & Meanders Ćehotina & Pljevlja \\
\hline 96 & Meanders Crnojevića River & Skadar Lake \\
\hline 97 & Bay Valdanos & Ulcinj \\
\hline 98 & Bay Pećin & Čanj \\
\hline 99 & Bay Jaz & Budva \\
\hline 100 & Dolina Djurovo oko & Karuč - Skadar Lake \\
\hline 101 & Dolina Kaludjerovo oko & Karuč - Skadar Lake \\
\hline 102 & Ada Bojana Island & Ulcinj \\
\hline 103 & Basin Zoganjsko jezero & Ulcinj \\
\hline 104 & Cliff - Dubovica & Buljarica \\
\hline 105 & Cliff Crvena srtijana & Petrovac \\
\hline 106 & Cliff Mogren & Budva \\
\hline 107 & Marine sand and gravel & Ulcinj \\
\hline 108 & Marine sand and gravel & Buljarica \\
\hline 109 & Island Lastavica & Boka Kotorska \\
\hline 110 & Island Sveti Nikola & Budva \\
\hline 111 & Island G.\& D. Katić & Petrovac \\
\hline 112 & Island Žabljak & Skadar Lake \\
\hline 113 & Peninsula Prevlaka & Tivat, Boka Kotorska \\
\hline 114 & Island Beška & Skadar Lake \\
\hline 115 & Island Vranjina & Skadar Lake \\
\hline 116 & Marine monadnock Kam & Sutomore \\
\hline 117 & $\begin{array}{l}\text { Limestone hum Spuška } \\
\text { glavica }\end{array}$ & Spuž \\
\hline 118 & $\begin{array}{l}\text { Space development of micro } \\
\text { karst forms }\end{array}$ & Bolj-Mt. Durmitor \\
\hline 119 & $\begin{array}{l}\text { Space development of micro } \\
\text { karst forms }\end{array}$ & Mt. Maganik \\
\hline 120 & Cockpit karst & Mt. Bjelič \\
\hline 121 & Cockpit karst & Mt. Sinjavina \\
\hline 122 & Cockpit karst & Mt. Pivska planina \\
\hline 123 & Karst table; Bolj & Mt. Durmitor \\
\hline 124 & Grahovsko polje & \\
\hline 125 & Cetinjsko polje & \\
\hline
\end{tabular}




\begin{tabular}{|c|c|c|}
\hline № & Name & Location \\
\hline 126 & Njeguško polje & \\
\hline 127 & Nikšićko polje & \\
\hline 128 & Polje Brezna & \\
\hline 129 & Nivacione doline & Šljeme - Mt. Durmitor \\
\hline 130 & Cirque-karsta doline & Jezerina, Mt. Lovćen \\
\hline 131 & Natural Bridge & Štuoc - Mt. Durmitor \\
\hline 132 & Natural Bridge & Komarnica \\
\hline 133 & Uvala Ugnji & Cetinje \\
\hline 134 & $\begin{array}{l}\text { Uvala Donje i Gornje } \\
\text { Ledenice }\end{array}$ & Risan \\
\hline 135 & Cirque Valoviti do & Mt. Durmitor \\
\hline 136 & Cirque Krstac & Mt. Stožac \\
\hline 137 & Cirque Bljuštur & Mt. Bioč \\
\hline 138 & Oštrikovački cirque & Mt. Volujak \\
\hline 139 & Cirque Ordeni doli & Mt. Volujak \\
\hline 140 & $\begin{array}{l}\text { Cirque basena Trnovačko } \\
\text { jezero }\end{array}$ & Mt. Maglić \\
\hline 141 & Cirque Carev do & Mt. Maglić \\
\hline 142 & Suha valov & Mt. Volujak \\
\hline 143 & Cirque Medjukomlje & Mt. Komovi \\
\hline 144 & Cirque Mojan & Mt. Prokletije \\
\hline 145 & Cirque Surdup & Mt. Žijovo \\
\hline 146 & Valov Gorni i Donji do & Mt. Bioč \\
\hline 147 & Valov Grbaja & Gusinje \\
\hline 148 & Valov Ropojan & Gusinje \\
\hline 149 & Moraine in the Velikoj Kalica & Mt. Durmitor \\
\hline 150 & Moraine Govedji breg & Trnovačko jezero Lake \\
\hline 151 & Moraine Mačja stopa & Dragaljsko polje \\
\hline 152 & Nunatak Stožina & Mt. Durmitor \\
\hline 153 & Nunatak Stolac & Mt. Volujak \\
\hline 154 & Nunatak Visoki kom & Mt. Volujak \\
\hline 155 & Carine, periglacial relief & Mt. Komovi \\
\hline 156 & Cave Vjetrena Brda & Mt. Durmitor \\
\hline 157 & Cave Mali Lomni do & Mt. Durmitor \\
\hline 158 & Cave Uviti do & Mt. Durmitor \\
\hline 159 & Cave Pribatov do & Mt. Maganik \\
\hline 160 & Cave Stožac & Mt. Kapa Moračka \\
\hline 161 & Cave Majstori & Mt. Lovćen \\
\hline 162 & Cave Duboki do & Njeguši \\
\hline 163 & Pestingradska jama Cave & Kotor \\
\hline 164 & $\begin{array}{l}\text { Pećina u Djavoljim firovima } \\
\text { Cave }\end{array}$ & Bistrica - Bjelo Polje \\
\hline 165 & Lipska pećina Cave & Dobrsko selo - Cetinje \\
\hline 166 & Začirska pećina Cave & Začir, Cetinje \\
\hline 167 & Pećina Grbočica Cave & Virpazar \\
\hline 168 & Cetinjska pećina Cave & Cetinje \\
\hline 169 & Džupanska pećina Cave & Lubnica, Berane \\
\hline 170 & Ledena pećina Cave & Mt. Durmitor \\
\hline 171 & $\begin{array}{l}\text { Waterfall in the river } \\
\text { Perućici }\end{array}$ & Danilovgrad \\
\hline
\end{tabular}

\begin{tabular}{|c|c|c|}
\hline № & Name & Location \\
\hline 172 & Waterfall Skakavac & Vusanje, Gusinje \\
\hline 173 & Waterfall in the Skakavica & Komarnica \\
\hline 174 & Estavela Gornjepoljski vir & Nikšić \\
\hline 175 & Estavela Gurdić & Kotor \\
\hline 176 & $\begin{array}{l}\text { Intermittent spring } \\
\text { Zaslapnica }\end{array}$ & Zaslap, Grahovsko polje \\
\hline 177 & Spring Glava Bistrice & Bijelo Polje \\
\hline 178 & Spring Glava Zete & Danilovgrad \\
\hline 179 & Oboštičko vrelo Spring & Danilovgrad \\
\hline 180 & Oraška jama Spring & Danilovgrad \\
\hline 181 & Vrelo Škurda Spring & Kotor \\
\hline 182 & Vrelo Sopot Spring & Risan \\
\hline 183 & Vrelo Spila Spring & Risan \\
\hline 184 & Vrelo Ljuta Spring & Orahovac, Kotor \\
\hline 185 & Vrelo Perućac Spring & Bogetići \\
\hline 186 & Vrelo Glava Ćehotine Spring & Pljevlja \\
\hline 187 & Alipašini izvori Spring & Gusinje \\
\hline 188 & Waterfall Djavolje lazi & Tara River, Bistrica \\
\hline 189 & Vrelo Ravnjak Spring & Bistrica \\
\hline 190 & Trnovačko jezero Lake & Mt. Maglić \\
\hline 191 & $\begin{array}{l}\text { Veliko \& Malo Stabanjsko } \\
\text { jezero Lake }\end{array}$ & Plužine \\
\hline 192 & Crno jezero Lake & Mt. Durmitor \\
\hline 193 & Škrčko jezero Lake & Mt. Durmitor \\
\hline 194 & Zminje jezero Lake & Mt. Durmitor \\
\hline 195 & Pošćensko jezero Lake & Mt. Durmitor \\
\hline 196 & Svrablje jezero Lake & Mt. Durmitor \\
\hline 197 & Riblje jezero Lake & Mt. Durmitor \\
\hline 198 & Poščensko jezero Lake & Komarnica \\
\hline 199 & Zminičko jezero Lake & Mt. Sinjevina \\
\hline 200 & Biogradsko jezero Lake & Mt. Bjelasica \\
\hline 201 & Jezero Ursulovac Lake & Mt. Bjelasica \\
\hline 202 & Pešića jezero Lake & Mt. Bjelasica \\
\hline 203 & Šiško jezero Lake & Mt. Bjelasica \\
\hline 204 & Kapetanovo jezero Lake & Mt. Moračke planine \\
\hline 205 & $\begin{array}{l}\text { Brnjičko [Manito] jezero } \\
\text { Lake }\end{array}$ & Mt. Moračke planine \\
\hline 206 & Visitorsko jezero Lake & Mt.Visitor \\
\hline 207 & Rikavičko jezero Lake & Mt. Žiovo \\
\hline 208 & Bukumirsko jezero Lake & Mt. Žiovo \\
\hline 209 & Terra rosa & Luštica \\
\hline 210 & Wetlands & Skadar Lake \\
\hline 211 & Wetlands & Žabljak \\
\hline 212 & Wetlands & Plavsko jezero \\
\hline 213 & Crvena stijena - Paleolithic & Petrovići, Nikšić \\
\hline 214 & Bioče Middle Paleolithic & Bioče \\
\hline 215 & $\begin{array}{l}\text { Cave Vruća Paleolithic and } \\
\text { Mesolithic }\end{array}$ & Canyon Mala rijeka \\
\hline 216 & Mališina stijena - Paleolithic & Mataruge, Pljevlja \\
\hline 217 & Medena stijena - Paleolithic & Canyon Ćehotina, Pljevlja \\
\hline
\end{tabular}

